\title{
Dissolution of wood components during hot water extraction of birch
}

\author{
Joanna Wojtasz-Mucha ${ }^{1,2} \cdot$ Merima Hasani $^{1,2} \mathbb{D} \cdot$ Hans Theliander $^{1,2}$
}

Received: 20 April 2020 / Accepted: 6 March 2021 / Published online: 5 April 2021

(C) The Author(s) 2021

\begin{abstract}
Autohydrolysis-based pretreatments enable extraction of hemicellulose from wood tissue prior to the paper pulp cooking processes enabling their further use as platform chemicals and in material applications. In this study, hot water extraction of birch meal was conducted in a small flow-through system. The combination of high surface area of the milled material with increased driving force induced by constant flow of freshwater, together with fast evacuation of extract, enabled a detailed study of the dissolution process. Based on the findings, deeper insight into acidification and autohydrolysis progress was obtained.
\end{abstract}

\section{Introduction}

In the light of environmental and climate crisis, there is an urge for use of sustainable resources for chemicals, materials and fuel production. Today, the major biobased material is paper pulp for various paper and board products. However, the current major technology such as kraft (about $75 \%$ of all produced paper pulp) or sulfite (about $5 \%$ of the produced pulp) pulping is based on solubilization/degradation of lignin for separation of cellulose, causing at the same time degradation of hemicelluloses. These processes have a material yield of about $50 \%$. The remaining $50 \%$ is normally incinerated.

An efficient fractionation of the main constituents in the wood would, apart from various grades of cellulose pulp, provide the base for a wide range of hemicelluloses and lignin products. Lignin with its aromatic structures has a great potential to be the base for chemicals and biofuel production. In the sulfite process, the separated hemicelluloses in the most degraded form can be used as sugar streams for

Joanna Wojtasz-Mucha

wojtasz@chalmers.se

1 Department of Chemistry and Chemical Engineering, Chalmers University of Technology, 41296 Gothenburg, SE, Sweden

2 Wallenberg Wood Science Center, The Royal Institute of Technology, 10044 Stockholm, SE, Sweden 
bioethanol production and further as platform chemicals. In the kraft process, only various sugar acids are produced which are incinerated. However, when recovered as higher molecular structures, they show a wide range of potential applications, such as packaging materials (Mikkonen et al. 2010; Chen et al. 2016; Kale et al. 2007; Mikkonen and Tenkanen 2012; Stevanic et al. 2012; Escalante et al. 2012) and films (Zhang and Whistler 2004), multifunctional emulsifiers and stabilizers for both food and technical applications (Lehtonen et al. 2018; Valoppi et al. 2019), tunable hydrogels for pharmaceuticals (Markstedt et al. 2017; Lindblad et al. 2005; Gao et al. 2016) as well as nanoparticles for medical (Wurm and Weiss 2014) and food applications (Prakasham et al. 2009).

While lignin can be recovered from the spent cooking liquors (e.g., by LignoBoost or as lignosulfonates in sulfite liquors), recovery of hemicelluloses must be done prior to the delignification to enable extraction of oligomeric or polymeric structures. The pretreatments based on autohydrolysis such as hot water extraction and steam explosion seem to be very promising as they generally do not require addition of chemicals.

One interesting characteristic of autohydrolysis is that the hydrogen ion does not need to be transported into the material. The wood tissue is in general acidic due to the presence of free acids and acidic groups that can be released as acetic, formic and uronic acids (Fengel and Wegener 1984; Sundqvist et al. 2006), for example, the $\mathrm{pH}$ of the aqueous solution within birch tissue is in the range of 4.18-4.79 at room temperature (Lachowicz et al. 2019). Despite the presence of protons in the cell wall, autohydrolysis reactions are not significant at low temperatures, but when the wood is heated, the $\mathrm{pH}$ decreases even further due to several different organic acids, as mentioned above, some present from the beginning and others produced. Kuitunen et al. (2013) studied the deacetylation kinetics of HWE in batch reactor by a phenomenological modeling approach based on experimental results of Borrega et al. (2011) and pKa values of UA computed at relevant temperatures based on NMR-determination by Teleman et al. (1995). This study could also point out the enhancing role of uronic acids and the cation exchange properties of wood tissue (the findings indicated a considerable Donnan effect in spite of rather low $\mathrm{pH}$ ), but also the possibility of metal ions neutralizing part of the acids. In a flow-through setup, Kilpeläinen et al. (2012) have studied pH variations in HWE of birch sawdust over a temperature range and over time (at $180{ }^{\circ} \mathrm{C}$ ) as a function of material size (Kilpeläinen et al. 2014). They showed potential of the flow-through extraction of xylan with varied acetate content, the process benefitting from small particle size and a high packing degree. Yet, for improved understanding of this complex process, there is a need for additional time-resolved information.

Garrote et al. (2001) proposed a theory describing the course of events during autohydrolysis of wood: The deacetylation at the beginning of the process depends on the availability of protons as the rate-limiting factor, causing generation of acetic acid, which further decreases the $\mathrm{pH}$ and thus increases the reaction rate. Finally, due to decreasing concentration of the substrate (acetylated hemicellulose), the reaction rate decreases toward the end of the treatment. Kapu et al. (2016) used a simplistic model to describe $\mathrm{pH}$ during mild acid hydrolysis and autohydrolysis of bamboo. They concluded that the proton concentration 
follows a complex behavior governed by weak-acid equilibrium of the acetic acid released from hemicelluloses, equilibrium created by water dissociation and ash neutralization. However, Bouchard et al. (1991) and Laser et al. (2002) pointed out that the deacetylation is fairly limited in comparison with the total acetate content, so there should be another driving force behind the hydrolysis. Thus, acidification during autohydrolysis includes the presence of other acidic moieties (e.g., glucuronic acids) and is more complex than assumed in the models purely based on acetic acid. Furthermore, it is not unlikely that different acids may have the major influence at different stages of the autohydrolysis. Nevertheless, among other things, the fact that the active constituents are a part of the hemicellulose/ lignin matrix implies that the deprotonation/production of hydrogen ions occurs, more or less, instantaneously throughout the cell wall when a sufficiently high temperature has been reached. Furthermore, since the hydrogen ions are small, it can be expected that they will be quickly distributed evenly in the cell wall, but also rather quickly out from the cell wall and equilibrate with the surroundings (when wood chips are used initially mostly with the liquid in the lumen).

The general course of events for autohydrolysis may, thus, be described by the following steps: (a) heating up of the wood tissue; (b) deprotonation of acids (e.g., 4- $O$-methyl glucuronic acids) and/or due to deacetylation and subsequent release of hydronium ions related to acetic acid leading to lower $\mathrm{pH}$; (c) mass transport of hydrogen ions in the cell wall simultaneously with reactions (acid hydrolysis of carbohydrates, continued deacetylation and probably some condensation reactions with lignin) followed by solubilization of reaction products; (d) mass transport of hydrogen ions (fast) and solubilized reaction products out of the cell wall; (e) further degradation of the dissolved wood constituents in the surrounding liquid.

The autohydrolysis may be performed in batch or flow-through setups with the latter having a great advantage of continuous removal of extracted products minimizing further degradation of the dissolved wood constituents when the temperature is lowered. The residence time of the extracts in the vessel can also be tuned by size of the flow-through equipment and flow rate. For instance, Leppänen et al. (2011) performed hot water extraction in a small flow-through setup of $200 \mathrm{mg}$. Although the benefit of such small equipment is a well-controlled treatment process, small amounts of the material limit the potential for extensive analyses of the resulting materials. Several studies are also based on the accelerated solvent extractor (Song et al. 2008, 2012; Ahmad et al. 2018), which is a setup of multiple small batch reactors that can be extracted simultaneously. Moreover, a cascade reactor setup was used to study solid-liquid dissolution kinetics during extraction of hemicelluloses from spruce sapwood (Grénman et al. 2011). Finally, a somewhat intermediate solution using a continuous mix batch reactor was also proposed for the extraction of birch (Jara et al. 2019). Such a configuration requires large quantities of water to be used, which can make analysis more difficult.

Apart from experimental setup, there are other process parameters to be controlled: temperature, size of the material (from wood chips to wood meal) and packing of the reactor (Kilpeläinen et al. 2014; Lora and Wayman 1978; Garrote et al. 1999; Tarasov et al. 2018). The most commonly used temperature range includes 160-280 ${ }^{\circ} \mathrm{C}$ (Borrega et al. 2011; Chen et al. 2010; Kilpeläinen et al. 
2014; Garrote et al. 1999; Gallina et al. 2016), while extraction at temperatures below $200{ }^{\circ} \mathrm{C}$ is generally considered relatively mild and investigated to a lesser extent.

Hardwood has a great potential as a substrate in autohydrolysis as it consists of highly acetylated xylan and has high fractions of syringyl units in lignin, which are less prone to condensation compared with softwood lignin (Sixta 2006). The main hemicellulose in hardwood is xylan with a molecular weight between 5.6 and $40 \mathrm{kDa}$. It seems to be impossible to extract such big structures out of the cell wall without depolymerization, as high molecular weight xylan presumably has low solubility and is likely partly covalently bound to the lignin matrix. Therefore, autohydrolysis needs to occur in order to extract xylan out of the wood tissue.

The aim of this work was to improve the mechanistic understanding behind the autohydrolysis of hardwood tissue. Therefore, the autohydrolysis process was studied using a small flow-through reactor allowing comprehensive investigation of structural changes and underlying mechanisms. The system used was accommodating approximately $6 \mathrm{~g}$ of wood meal and it is known to provide uniform reaction conditions throughout the reactor (Bogren et al. 2009). The experiments were carried out at 130,150 and $170{ }^{\circ} \mathrm{C}$ for up to $120 \mathrm{~min}$, and both solid and liquid fractions were analyzed.

\section{Materials and methods}

\section{Materials}

Birch was ground in a Wiley mill and sieved to a size below $1 \mathrm{~mm}$. All chemicals were purchased from Sigma-Aldrich (St. Louis, MO, USA) and used as received.

\section{Methods}

\section{Flow-through extraction}

The flow-through experiments were conducted in an equipment described earlier by Bogren et al. (2009), composed of high-pressure pump, a steel column $(300 \times 7.8 \mathrm{~mm})$, PEG filled heating bath, coiling in front of the column for heating and behind the column for instant cooling (submerged in cold water). Approximately $6 \mathrm{~g}$ of birch wood meal was packed carefully in the reactor and water was pumped through at $5 \mathrm{ml} / \mathrm{min}$ flow. The oil bath was set to 130,150 or $170{ }^{\circ} \mathrm{C}$, and the treatment was carried for 30,60 or $120 \mathrm{~min}$. The liquor samples were collected in time intervals at $0-10,10-20,20-40,40-60,60-80,80-100,100-120 \mathrm{~min}$.

The solid residues were evacuated from the column and placed in $300 \mathrm{ml}$ deionized water; after dewatering, additional $700 \mathrm{ml}$ was used for washing. After that, the material was oven dried at $105{ }^{\circ} \mathrm{C}$ (Fig. 1). 


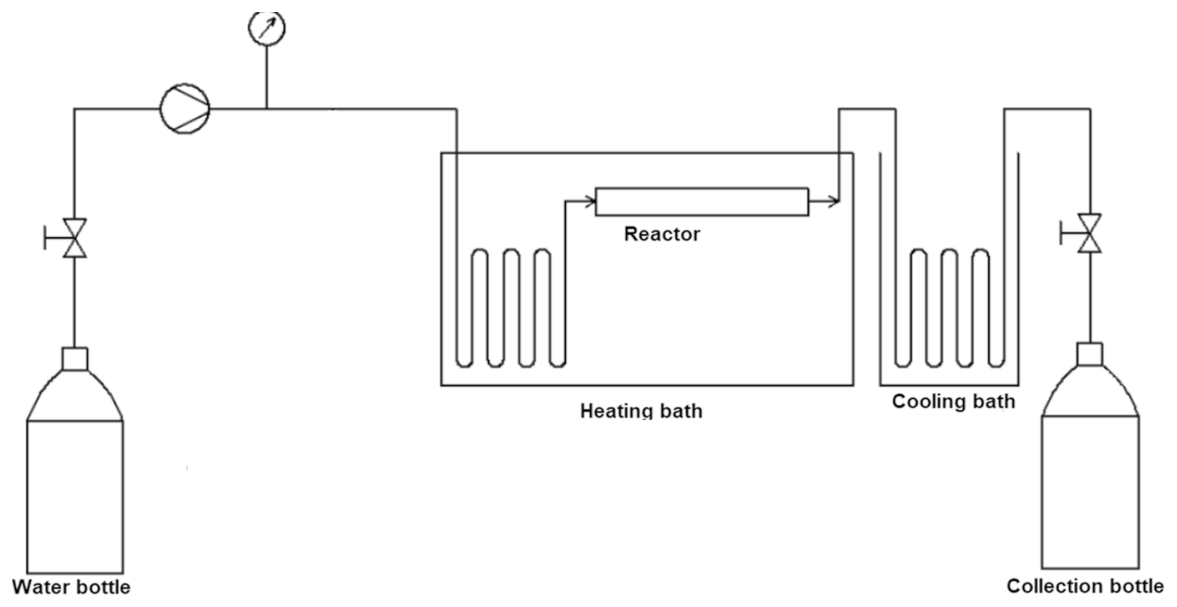

Fig. 1 Schematic diagram of the small-scale flow-through reactor used

\section{$\mathrm{pH}$ and dry content}

The $\mathrm{pH}$ of the liquors was determined at room temperature directly after extraction. Dry content was established by gravimetrical measurement before and after drying of the liquor sample at $105^{\circ} \mathrm{C}$.

\section{Lignin quantification}

Klason and acid-soluble lignin were quantified after two-stage, complete acid hydrolysis of the sample according to Tappi T222 om-02 with minor modifications. The insoluble fraction determined gravimetrically was considered as Klason lignin. The acid-soluble lignin was determined by absorbance measurement at $205 \mathrm{~nm}$.

\section{Carbohydrate analysis}

Carbohydrates in solids and liquor were quantified with the use of HPAEC Dionex ICS-5000 system equipped with a CarboPac PA1 column and Chromeleon 7 Chromatography Data System, Version 7.1.0.898.

The free carbohydrate monomers were measured by the addition of internal standard and injecting into the system without further preparations. The oligomeric carbohydrates were quantified after a two-stage complete acid hydrolysis. The liquor samples were freeze-dried prior to the hydrolysis. The quantified sugars were corrected by the hydrolysis yield reported earlier by Wojtasz-Mucha et al. (2017).

GC-MS The compounds in the freeze-dried liquor samples were investigated with GC-MS employing a method adapted from Sundberg et al. (1996). The components in the samples $(4 \mathrm{mg})$ were methanolyzed using a reagent consisting of 
$2.8 \mathrm{ml} \mathrm{Ac}-\mathrm{Cl}$ in $17.2 \mathrm{ml}$ anhydrous methanol. The samples were left to react at $80{ }^{\circ} \mathrm{C}$ for three hours. After evaporation, pyridine was used as a solvent and an internal sorbitol standard was added. The solvent in the samples was evaporated before the samples were silylated using $150 \mu \mathrm{l}$ hexamethyldisilazane and $80 \mu \mathrm{l}$ chlorotrimethylsilane as the silylation reagents. After silylation, the solvent was evaporated again and $2 \mathrm{ml}$ of diethyl ether was added to the dry samples; they were then filtered and injected into a GC-MS system.

Agilent 5975C, equipped with mass spectrometer (MS) detection operating in an electron ionization mode, was used.

A sample of $1 \mu \mathrm{l}$ was injected with the split ratio of 1:10. The separation was conducted using helium as the carrier gas $1 \mathrm{ml} / \mathrm{min}$ for the MS column (HP- 5MS, $30 \mathrm{~m}$ in length, $0.25 \mathrm{~mm}$ in internal diameter and $0.25 \mu \mathrm{m}$ in stationary phase thickness). The temperature in the injector was set to $300{ }^{\circ} \mathrm{C}$, followed by $28{ }^{\circ} \mathrm{C}$ for the $\mathrm{GC}$ oven for the first $2 \mathrm{~min}$, then raised to $140{ }^{\circ} \mathrm{C}$ at a rate of $20{ }^{\circ} \mathrm{C} / \mathrm{min}$, followed by an increase to $200{ }^{\circ} \mathrm{C}$ at a rate of $4{ }^{\circ} \mathrm{C} / \mathrm{min}$ and to $300{ }^{\circ} \mathrm{C}$ at a rate of $15{ }^{\circ} \mathrm{C} / \mathrm{min}$. The temperature of the $\mathrm{GC}$ oven was held at $300{ }^{\circ} \mathrm{C}$ for $5 \mathrm{~min}$. The MS source and the quadrupole temperature were set to 250 and $150{ }^{\circ} \mathrm{C}$, respectively. The NST MS search program (Version 2.0) operating on the NIST/EPA/ NIH Mass Spectral Database 2011 (NIST 11) was used to perform the spectral interpretations.

\section{Acetate analysis}

The acetic acid and acetate fraction in the samples were determined by use of KACET kit from Megazyme (Bray, Ireland). The quantification of acetate was executed after deacetylation by $1 \mathrm{~h}$ alkaline hydrolysis in $1 \mathrm{M} \mathrm{NaOH}(\mathrm{aq})$ at $70^{\circ} \mathrm{C}$.

\section{Degree of polymerization (DP) of cellulose}

$4 \mathrm{~g}$ solid residue was weighed for peracetic acid (PAA) delignification. The reaction was performed according to the procedure described by Kumar et al. (2013), with a $5 \%$ dry content and $5.5 \mathrm{~g}$ of PAA. After $53 \mathrm{~h}$ had passed, the remaining material was washed until neutral $\mathrm{pH}$ and stored frozen. Samples were air-dried overnight prior to viscosity measurements in $0.5 \mathrm{M} \mathrm{CED} \mathrm{(copper} \mathrm{(II)} \mathrm{ethylenedi-}$ amine) according to SCAN-C 15:62. The degree of polymerisation was calculated according to Immergut et al. (1953), see Eq. 1.

$$
\mathrm{DP}_{\eta}=0.75[\eta]
$$

\section{NMR spectroscopy}

$35 \mathrm{mg}$ of freeze-dried liquor was dissolved in DMSO-d6 and left overnight under stirring. The ${ }^{1} \mathrm{H}$ spectra were recorded at a $30^{\circ}$ pulse angle, a 6 s pulse delay, 1024 scans and $2.04 \mathrm{~s}$ acquisition time. The phase-sensitive qualitative HSQC 
spectra were recorded at a standard Bruker pulse sequence "hsqcedetgpsisp 2.3" with a $0.25 \mathrm{~s}{ }^{1} \mathrm{H}$ acquisition time, a $5.3 \mu \mathrm{s}{ }^{13} \mathrm{C}$ acquisition time, a $3 \mathrm{~s}$ interscan delay and a $1 \mathrm{JC}-\mathrm{H}$ coupling constant of $145 \mathrm{~Hz}$. Each spectrum was recorded for $4 \mathrm{~h}$.

\section{Results and discussion}

\section{Extraction yield and rate}

The results of hot water extraction of birch meal are presented in Table 1 where the results of the overall mass balance, masses of the extracted compounds and the composition of the residue solid material can be found. The overall mass balance is close to $100 \%$ and differs on average by $2.3 \%$ and at most $6 \%$. Relatively high dissolution yields were achieved with up to $43.8 \%$ of solid weight of the original wood removed upon treatment at $170{ }^{\circ} \mathrm{C}$ for $120 \mathrm{~min}$. Such a high dissolution yield was enabled by using flow-through reactor and milled wood sample, which is in agreement with Borrega and Sixta (2015), who found that the extraction yield of wood is dependent on both wood size and pretreatment system.

As the temperature increases, the acidic autohydrolysis and dissolution of the wood components occur at higher rates resulting in increasing extraction yield: At $130{ }^{\circ} \mathrm{C}$, only $2.6-10.8 \%$ was removed; at $150{ }^{\circ} \mathrm{C}$, extraction becomes significant after the first $30 \mathrm{~min}$; at $170{ }^{\circ} \mathrm{C}$, the extraction is relatively rapid initially and after the first $30 \mathrm{~min}$, limited amount of material is extracted as the main part of the extractable material is already extracted. The trends observed in the solid composition are in line with the dissolution rates presented in Fig. 2a.

Table 1 Total dissolved solids (TDS), yield and composition for the residue solid in comparison with original wood (b.d.: below detection limit)

\begin{tabular}{lllrllllllll}
\hline $\begin{array}{l}\text { Temp } \\
{ }^{\circ} \mathrm{C}\end{array}$ & $\begin{array}{l}\text { Time } \\
\mathrm{min}\end{array}$ & $\begin{array}{l}\text { TDS } \\
\%\end{array}$ & \multicolumn{1}{c}{ Yield } & $\begin{array}{l}\text { Ara } \\
\mathrm{mg} / \mathrm{g}\end{array}$ & Rha & Gal & Glu & Xyl & Man & Klason & Other \\
\hline Original wood & & 2.9 & 2.6 & 9.5 & 409.9 & 197.7 & 19.8 & 230.9 & 126.8 & & \\
& 30 & 2.6 & 101.1 & 2.4 & 2.9 & 10.0 & 401.0 & 206.6 & 22.3 & 210.1 & 130.0 \\
130 & 60 & 4.5 & 96.2 & 1.1 & 2.6 & 8.4 & 388.8 & 195.7 & 20.3 & 190.4 & 109.4 \\
& 120 & 10.8 & 99.6 & b.d & 2.3 & 6.1 & 383.4 & 175.9 & 18.8 & 176.6 & 124.7 \\
& 30 & 9.6 & 95.9 & 0.1 & 2.2 & 6.1 & 389.0 & 172.0 & 17.6 & 178.3 & 97.7 \\
150 & 60 & 29.8 & 100.7 & b.d & 1.5 & 2.0 & 372.1 & 92.5 & 11.7 & 148.8 & 80.6 \\
& 120 & 33.7 & 98.2 & b.d & b.d & 0.7 & 380.3 & 69.2 & 9.9 & 122.9 & 62.7 \\
& 30 & 36.3 & 106.0 & b.d & b.d & 0.8 & 378.5 & 61.3 & 7.6 & 144.2 & 104.7 \\
170 & 60 & 43.9 & 101.8 & 0.4 & b.d & b.d & 356.1 & 45.9 & 7.1 & 110.9 & 58.9 \\
& 120 & 43.8 & 98.6 & b.d & b.d & b.d & 348.2 & 39.9 & 4.7 & 94.1 & 61.0 \\
\hline
\end{tabular}




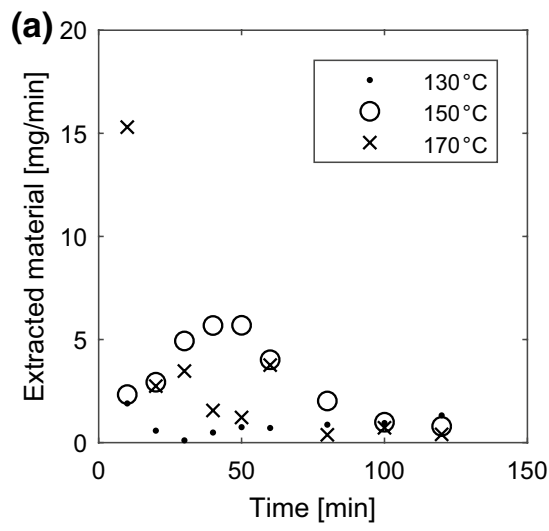

(C)

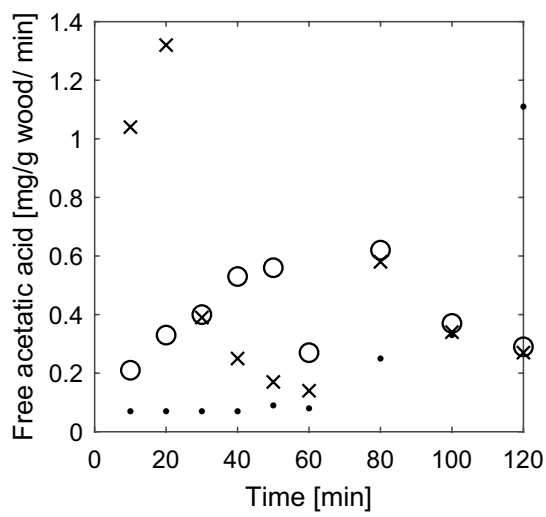

(b)

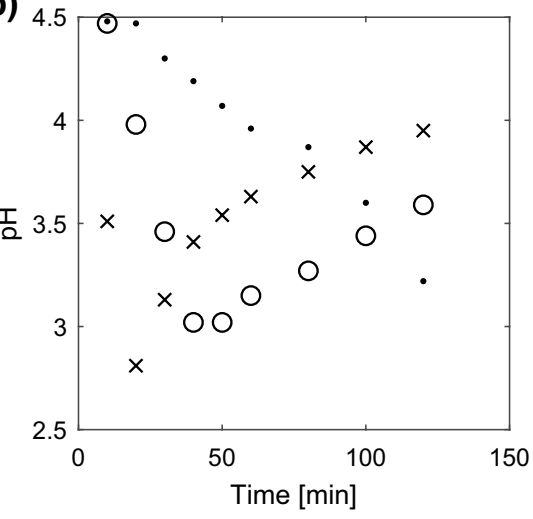

(d)

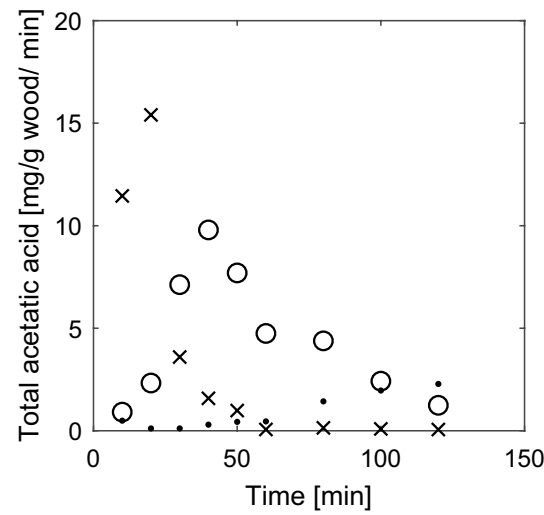

Fig. $2 \mathrm{pH}$ (a) and concentration of solids (b) in the extraction liquors compared with the amount of free acetic acid in the liquors (c) and acetic acid recovered from extracted sugars (d)

\section{pH}

In Fig. 2b, the pH of the extracted liquor at different times and temperatures can be found. It is obvious that there is a large difference if the three temperatures are compared.

At $170{ }^{\circ} \mathrm{C}$, the $\mathrm{pH}$ is quickly decreased to a minimum $(20 \mathrm{~min})$ and then slowly increases. The behavior at $150{ }^{\circ} \mathrm{C}$ is similar but the minimum comes later $(50 \mathrm{~min})$. For $130{ }^{\circ} \mathrm{C}$, the $\mathrm{pH}$ never reaches a minimum and the $\mathrm{pH}$ level is higher for the two higher temperatures.

The $\mathrm{pH}$ correlates relatively well with the dissolution rate in Fig. 2a, which was expected. 
Table 2 Acetic acid concentration in the native wood and solid residues after extraction at different conditions

\begin{tabular}{|c|c|c|c|c|c|}
\hline \multirow{3}{*}{$\begin{array}{l}\text { Temperature } \\
{ }^{\circ} \mathrm{C}\end{array}$} & \multirow{3}{*}{$\begin{array}{l}\text { Time } \\
\text { min }\end{array}$} & \multirow{3}{*}{$\begin{array}{l}\text { Acetic acid } \\
\text { in solid } \\
\mathrm{mg} / \mathrm{g} \text { wood }\end{array}$} & \multicolumn{2}{|c|}{$\begin{array}{l}\text { Acetic acid in } \\
\text { liquid }\end{array}$} & \multirow{3}{*}{$\begin{array}{l}\text { Overall } \\
\%\end{array}$} \\
\hline & & & Free & Esterified & \\
\hline & & & & & \\
\hline \multirow{4}{*}{$\begin{array}{l}\text { Native } \\
130\end{array}$} & & 38.62 & - & - & 100 \\
\hline & 30 & 37.33 & 0.21 & 0.72 & 99.1 \\
\hline & 60 & 35.42 & 0.45 & 1.91 & 97.8 \\
\hline & 120 & 33.06 & 2.13 & 7.59 & 110.8 \\
\hline \multirow[t]{3}{*}{150} & 30 & 30.74 & 0.94 & 10.36 & 108.9 \\
\hline & 60 & 15.57 & 2.30 & 32.60 & 130.7 \\
\hline & 120 & 11.01 & 3.57 & 40.64 & 143.0 \\
\hline \multirow[t]{3}{*}{170} & 30 & 9.73 & 2.75 & 30.45 & 111.2 \\
\hline & 60 & 2.89 & 3.30 & 33.09 & 101.7 \\
\hline & 120 & 5.94 & 4.49 & 33.38 & 113.5 \\
\hline
\end{tabular}

\section{Release of acetic acid}

As the temperature increases and the $\mathrm{pH}$ decreases, the hemicelluloses are partly broken up into shorter structures (monomers, oligomers and macro-molecules) and partly deacetylated, thus the extraction liquors contain both free acetic acid and acetylated oligosaccharides. Table 2 presents the amount of acetates in the solid residues and extracted constituents, as well as the free acetic acid amount in the liquors. The course of events of the extraction of free and esterified acetic acid can be observed in Fig. 2c and d.

Comparing the amounts of free and total acetate in the samples shows that most of the acetate is actually extracted in esterified form together with oligosaccharides. The latter is in agreement with earlier reports (Jara et al. 2019; Kilpeläinen et al. 2014; Tunc and van Heiningen 2008; Laser et al. 2002; Bouchard et al. 1991).

The extraction rate of free acetic acid and the $\mathrm{pH}$ show a good correlation for the extracted liquors analyzed (Fig. 2b, c). The limited deacetylation together with the strong correlation between the amount of released acetic acid and $\mathrm{pH}$ could be an indication of the deacetylation being governed by the availability of the protons. Therefore, an effort was made to investigate whether the $\mathrm{pH}$ is solely a function of the concentration of free acetic acid. $\mathrm{pH}$ estimated based on measured free acetate concentrations (assumed to only be dependent on the concentration of free acetic acid, with a $\mathrm{pKa}$ value of 4.74 used) was plotted along with the measured $\mathrm{pH}$, and the results are presented in Fig. 3. It appears that at the start, the main contribution to the $\mathrm{pH}$ can be assumed to be from the free acetic acid, but the measured $\mathrm{pH}$ is gradually decreasing while the estimated $\mathrm{pH}$ value is more or less constant for $130{ }^{\circ} \mathrm{C}$. In addition, at $150{ }^{\circ} \mathrm{C}$, the estimated $\mathrm{pH}$ values are more or less constant and higher than the measured value. At $170{ }^{\circ} \mathrm{C}$, the estimated value is higher and increases slightly. This suggests that there is some other acid (or acids) with lower pKa that is the primary hydrolytic agent 

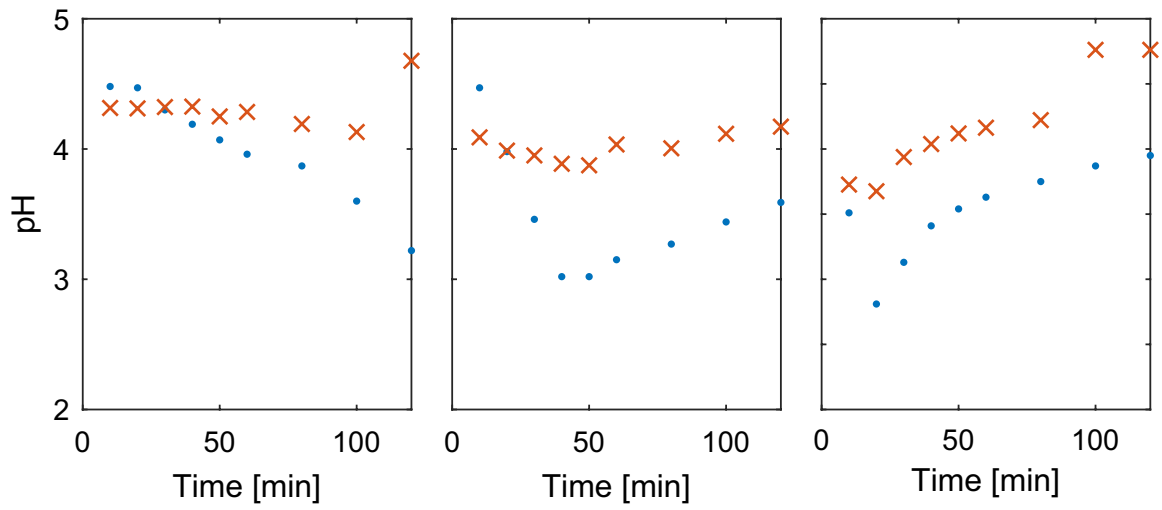

Fig. $3 \mathrm{pH}$ estimated based on free acetate (cross) and measured (dots) for temperatures 150 to $170{ }^{\circ} \mathrm{C}$ (left to right)

controlling the $\mathrm{pH}$. Glucuronic acid from xylan, galacturonic acid from pectin (both with pKa within 3.3-3.5 (Kohn and Kovac 1978)), as well as formic acid, formed through degradation of hexoses (Fengel and Wegener 1984; Sundqvist et al. 2006), could participate in this process. Finally, after long extraction time, the reaction rate could be affected by the decreasing concentration of the substrate (acetylated xylan) in the wood tissue.

Extraction at $130{ }^{\circ} \mathrm{C}$ causes very limited decrease in acetate content of the solid residue compared with the native wood, see Table 2 . A prominent decrease can be seen after extraction at $150{ }^{\circ} \mathrm{C}$ for time longer than $60 \mathrm{~min}$ and at $170{ }^{\circ} \mathrm{C}$. This set of data indicates a very strong correlation between the extent of deacetylation and increasing temperature, which might be caused by a strong temperature influence on the kinetics of the deprotonation reactions and deacetylation itself.

As shown in Table 2, there is some overestimation in the total amount of acetic acid quantified. The reason for this has not been investigated further. It can be noted that acetic acid has been identified as one of the degradation products from glucose under sub- and supercritical water treatment (Holgate et al. 1995).

\section{Overall composition of extracted liquors and solid residues}

The composition of the solid residue can be found in Table 1, the composition of the extracted liquors in Table 3 and the content of monomers in the extracted liquor in Table 4. The significant difference in concentration of the different constituents obtained at different temperatures is probably due to faster kinetics of the reactions at higher temperature and decreasing $\mathrm{pH}$. It is of great interest to correlate the changes in the solid fraction with the composition of the extracts, therefore in the text below, the behavior of each component will be discussed in more detail.

A fraction labeled Others consisting of the material not assigned to any of the fractions is most probably composed of fatty acids and degradation products. 
Table 3 Total composition of the freeze-dried liquor

\begin{tabular}{|c|c|c|c|c|c|c|c|c|c|}
\hline $\begin{array}{l}\text { Temp } \\
{ }^{\circ} \mathrm{C}\end{array}$ & $\begin{array}{l}\text { Time } \\
\text { min }\end{array}$ & $\begin{array}{l}\mathrm{Ara} \\
\mathrm{mg} / \mathrm{q}\end{array}$ & $\begin{array}{l}\text { Gal } \\
\text { wood }\end{array}$ & Glu & Xyl & Man & Klason & ASL & Others \\
\hline \multirow[t]{9}{*}{130} & 10 & 0.3 & 0.4 & 2.9 & 0.2 & 1.1 & 9.7 & 1.2 & 3.0 \\
\hline & 20 & 0.3 & 0.2 & 0.5 & 0.1 & 0.1 & 3.1 & 0.4 & 1.1 \\
\hline & 30 & 0.1 & 0.0 & 0.1 & 0.1 & 0.0 & 0.4 & 0.1 & 0.3 \\
\hline & 40 & 0.3 & 0.2 & 0.3 & 0.4 & 0.0 & 2.0 & 0.4 & 1.2 \\
\hline & 50 & 0.4 & 0.3 & 0.4 & 1.0 & 0.0 & 3.0 & 0.7 & 1.7 \\
\hline & 60 & 0.4 & 0.2 & 0.3 & 1.2 & 0.0 & 2.5 & 0.6 & 1.7 \\
\hline & 80 & 0.5 & 0.5 & 0.7 & 3.6 & 0.2 & 5.5 & 1.1 & 5.3 \\
\hline & 100 & 0.4 & 0.5 & 0.6 & 5.0 & 0.2 & 4.8 & 1.2 & 6.5 \\
\hline & 120 & 0.3 & 0.7 & 0.6 & 8.4 & 0.2 & 6.0 & 1.6 & 8.7 \\
\hline \multirow[t]{9}{*}{150} & 10 & 0.8 & 0.6 & 3.5 & 1.2 & 1.6 & 11.6 & 1.0 & 3.0 \\
\hline & 20 & 1.0 & 0.8 & 1.5 & 6.8 & 0.7 & 9.4 & 1.4 & 7.8 \\
\hline & 30 & 0.7 & 1.1 & 1.3 & 16.6 & 0.6 & 10.4 & 2.3 & 16.3 \\
\hline & 40 & 0.2 & 1.0 & 1.1 & 18.7 & 0.6 & 10.6 & 2.8 & 21.7 \\
\hline & 50 & 0.0 & 0.6 & 0.6 & 13.4 & 0.0 & 12.0 & 2.0 & 28.4 \\
\hline & 60 & 0.0 & 0.6 & 0.9 & 13.3 & 0.4 & 9.6 & 2.1 & 13.2 \\
\hline & 80 & 0.0 & 0.5 & 1.1 & 12.7 & 0.6 & 11.6 & 2.1 & 11.7 \\
\hline & 100 & 0.0 & 0.3 & 0.6 & 5.6 & 0.3 & 5.9 & 1.1 & 6.0 \\
\hline & 120 & 0.0 & 0.2 & 0.6 & 4.2 & 0.2 & 4.8 & 0.9 & 4.8 \\
\hline \multirow[t]{9}{*}{170} & 10 & 3.4 & 3.7 & 10.0 & 51.0 & 5.8 & 40.3 & 6.5 & 58.8 \\
\hline & 20 & 0.1 & 2.4 & 3.7 & 54.2 & 1.8 & 33.3 & 7.7 & 58.5 \\
\hline & 30 & 0.0 & 0.5 & 1.1 & 9.8 & 0.6 & 12.0 & 2.2 & 9.9 \\
\hline & 40 & 0.0 & 0.1 & 0.7 & 3.3 & 0.3 & 5.1 & 0.8 & 3.5 \\
\hline & 50 & 0.0 & 0.1 & 0.4 & 1.6 & 0.1 & 2.7 & 0.5 & 1.6 \\
\hline & 60 & 0.0 & 0.0 & 0.4 & 1.5 & 0.1 & 3.6 & 0.5 & 0.6 \\
\hline & 80 & 0.0 & 0.1 & 0.7 & 1.9 & 0.2 & 3.5 & 0.6 & 2.1 \\
\hline & 100 & 0.0 & 0.0 & 0.7 & 1.6 & 0.2 & 3.2 & 0.6 & 1.5 \\
\hline & 120 & 0.0 & 0.0 & 0.8 & 1.7 & 0.1 & 3.1 & 0.7 & 1.4 \\
\hline
\end{tabular}

\section{Hemicelluloses}

\section{Glucuronoxylan}

The extraction of xylan exhibits a strong temperature and $\mathrm{pH}$ dependency with $11 \%$ of original xylan removed after $120 \mathrm{~min}$ at $130{ }^{\circ} \mathrm{C}, 61 \%$ at $150{ }^{\circ} \mathrm{C}$ and $77 \%$ at $170{ }^{\circ} \mathrm{C}$ (Table 1). The mechanism behind this could be threefold. First, the increased proton concentration promotes the dissolution of xylan by accelerating the depolymerization. Moreover, it is reasonable to assume that the local concentrations of protons and xylan will be significantly higher in the cell wall than in the extraction liquor. Thus, the deacetylation will occur at significantly higher rates in the cell wall compared with deacetylation of the extracted dissolved xylan. Finally, knowing that the birch xylan carries glucuronic acid side groups at every tenth xylose unit in 
Table 4 Monomers detected in freeze-dried liquors

\begin{tabular}{|c|c|c|c|c|c|c|c|}
\hline $\begin{array}{l}\text { Temperature } \\
\left({ }^{\circ} \mathrm{C}\right)\end{array}$ & $\begin{array}{l}\text { Time } \\
(\mathrm{min})\end{array}$ & $\begin{array}{l}\text { Ara } \\
(\mathrm{mg} / \mathrm{g}\end{array}$ & $\begin{array}{l}\text { Gal } \\
\text { wood) }\end{array}$ & Glu & Xyl & Man & Sum \\
\hline \multirow[t]{9}{*}{130} & 10 & 0.06 & 0.01 & 0.04 & 0.03 & 0.00 & 0.14 \\
\hline & 20 & 0.06 & 0.01 & 0.01 & 0.02 & 0.00 & 0.09 \\
\hline & 30 & 0.00 & 0.00 & 0.00 & 0.00 & 0.00 & 0.01 \\
\hline & 40 & 0.08 & 0.01 & 0.01 & 0.02 & 0.00 & 0.12 \\
\hline & 50 & 0.11 & 0.02 & 0.01 & 0.03 & 0.00 & 0.17 \\
\hline & 60 & 0.09 & 0.02 & 0.01 & 0.03 & 0.00 & 0.15 \\
\hline & 80 & 0.03 & 0.05 & 0.02 & 0.11 & 0.00 & 0.21 \\
\hline & 100 & 0.15 & 0.05 & 0.02 & 0.12 & 0.00 & 0.34 \\
\hline & 120 & 0.01 & 0.05 & 0.01 & 0.13 & 0.00 & 0.20 \\
\hline \multirow[t]{9}{*}{150} & 10 & 0.30 & 0.03 & 0.08 & 0.09 & 0.00 & 0.52 \\
\hline & 20 & 0.46 & 0.09 & 0.04 & 0.21 & 0.00 & 0.80 \\
\hline & 30 & 0.27 & 0.12 & 0.11 & 0.36 & 0.00 & 0.86 \\
\hline & 40 & 0.00 & 0.12 & 0.02 & 0.01 & 0.66 & 0.80 \\
\hline & 50 & 0.00 & 0.07 & 0.03 & 0.00 & 0.96 & 1.06 \\
\hline & 60 & 0.07 & 0.12 & 0.09 & 0.58 & 0.00 & 0.86 \\
\hline & 80 & 0.06 & 0.10 & 0.04 & 0.48 & 0.00 & 0.67 \\
\hline & 100 & 0.02 & 0.05 & 0.03 & 0.34 & 0.00 & 0.45 \\
\hline & 120 & 0.02 & 0.05 & 0.04 & 0.34 & 0.01 & 0.45 \\
\hline \multirow[t]{9}{*}{170} & 10 & 0.59 & 0.22 & 0.24 & 0.79 & 0.00 & 1.85 \\
\hline & 20 & 0.13 & 0.26 & 0.09 & 1.24 & 0.00 & 1.71 \\
\hline & 30 & 0.05 & 0.14 & 0.15 & 0.69 & 0.00 & 1.03 \\
\hline & 40 & 0.02 & 0.05 & 0.07 & 0.30 & 0.00 & 0.44 \\
\hline & 50 & 0.01 & 0.02 & 0.03 & 0.15 & 0.00 & 0.21 \\
\hline & 60 & 0.01 & 0.02 & 0.04 & 0.15 & 0.00 & 0.22 \\
\hline & 80 & 0.01 & 0.02 & 0.06 & 0.20 & 0.00 & 0.30 \\
\hline & 100 & 0.01 & 0.01 & 0.06 & 0.18 & 0.00 & 0.27 \\
\hline & 120 & 0.01 & 0.01 & 0.07 & 0.19 & 0.01 & 0.29 \\
\hline
\end{tabular}

the chain, it is likely that extraction of the glucuronic acid out of the wood tissue, along with a possible de-esterification of those involved in esters (e.g., in LCCs), could affect the $\mathrm{pH}$ of the extraction liquor. For example, the increase in the $\mathrm{pH}$ after reaching a minimum value at 150 and $170{ }^{\circ} \mathrm{C}$ correlates with the extraction of most of the available glucuronoxylan and nearly depletion of available acetate in the material.

As shown in Table 4, hardly any xylan was detected in monomeric form even after the most severe treatment. In fact, there might have been a limited monomeric xylose released and then further degraded to furfural. Considering the amount of xylan quantified after acid hydrolysis, it can be concluded that most of the xylan is extracted in oligomeric form.

According to earlier studies, there are likely two fractions of xylan with different extractability (Conner 2007; Jara et al. 2019; Dammström et al. 2009; 
Ruel et al. 2006). One fraction is closely associated with cellulose, while the other could be bound to lignin. Those two fractions could also be different in their structure, with cellulose-xylan being more acetylated while the lignin-xylan could be less acetylated but has more 4- $O$-methylglucuronic acid side chains (Dammström et al. 2009). The more difficult to remove cellulose-associated fraction is estimated to constitute up to $25 \%$ of the total xylan (Jara et al. 2019).

Jara et al. (2019) claims that in red maple, there could actually be three fractions differing in acetylation pattern, molecular mass and LCC bonds. In the present study, the average number of acetate groups per 10 xylose units in residual solid decreases only slightly with the increase in extraction yield, approximately from 4.3 to 3.3 (based on the data in Tables 1 and 2). It can, however, not be simply assessed whether it is due to deacetylation or the presence of different fractions with regard to acetylation (Fig. 4).

\section{Glucomannan}

Glucomannan can constitute up to $4 \%$ of the total mass of birch and it is comprised of mannose and glucose in a ratio of approximately 1:1-2:1 (Timell 1969; Fengel and Wegener 1984). As there are other sources of glucose in the analyzed samples, such as cellulose and starch, trends in GM content are evaluated based on mannose concentration which can only be found in GM.

Mannose is extracted mostly during the first 10-20 min of the extraction. The total amount of mannose detected increased with temperature. At the highest treatment temperature, $62-76 \%$ of GM is released.

No free monomeric mannose was detected, thus glucomannan is most probably released in oligomeric form.
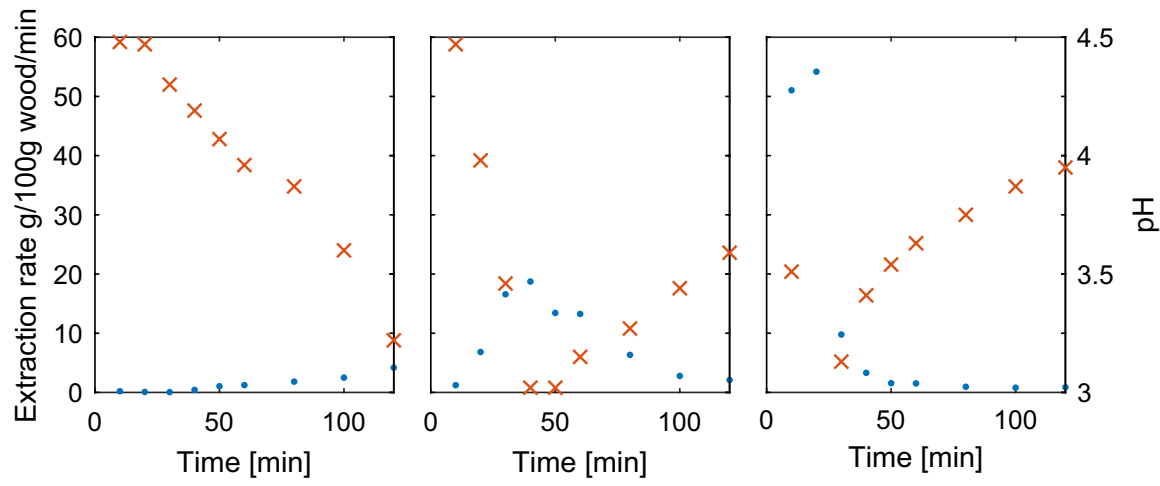

Fig. 4 Oligomeric xylose extraction rate in $\mathrm{g} / 100 \mathrm{~g} / \mathrm{min}$ (dots) in comparison with the $\mathrm{pH}$ (cross) for temperatures 150 to $170{ }^{\circ} \mathrm{C}$ (left to right) 


\section{Arabinogalactan}

Arabinose and galactose were found in the extraction liquors both as oligomers and monomers (Tables 3,4). The origin of those is probably arabinogalactan, constituting up to $3 \%$ or birch wood (Fengel and Wegener. 1984). Arabinogalactan (gal/ ara 6:1) is heavily branched with a molecular weight of 29-59 kDa. The presence of free arabinose and galactose, as well as oligomeric galactan, is most probably related to the hydrolysis of AG side chains. AG is easily dissolved and its side chains are probably partially cleaved off due to the acidic conditions, which is in line with similar observation made for spruce (Wojtasz-Mucha et al. 2020).

\section{Klason lignin}

When the liquor and solid residues composition were compared, it was concluded that the sum of the Klason fraction found in the solid residue and the liquors exceeds the amount of lignin in native wood. This is most probably a result of carbohydrate degradation products (e.g., furfural) condensing together with lignin during pretreatment or precipitating together with extracted lignin and forming insoluble fraction (Overend et al. 1987; Borrega et al. 2011).

In the course of the event of hot water extraction, the fraction of Klason lignin in solid residue decreases in comparison with the original material, which corresponds to significant lignin fraction in the extracts. The overall extraction becomes more efficient at higher temperatures.

The dissolution of lignin seems to be extremely significant in the beginning of the treatment, which was also observed for red maple wood by Jara et al. (2019). One reason may be that there is an easily extractable lignin fraction, having no or limited covalent bonds to the other cell wall constituents. Another possible reason may be a quick release due to some middle lamella and primary cell wall structures being exposed since wood powder is used.

In general, the lignin extraction pattern often follows the xylan behavior, and these two components are usually co-extracted, which in turn might indicate the presence of lignin carbohydrate complexes (LCC). This could contribute to a high overall lignin removal rate-after $120 \mathrm{~min}$ at $170{ }^{\circ} \mathrm{C}$ up to $60 \%$ of original lignin and $80 \%$ of xylan are removed.

After the most extensive extraction, $40 \%$ of lignin remained in the solid residue. The presence of such hard-to-remove fraction together with the indications of easily extractable and LCC lignin might suggest the presence of different lignin types as discussed in earlier studies (Ruel et al. 2006; Jara et al. 2019).

\section{Cellulose}

As shown in Table 1, cellulose content remains relatively stable during the hot water extraction. At temperatures lower than $170{ }^{\circ} \mathrm{C}$, the glucose content in wood decreases by less than $10 \%$. Interestingly, at $170{ }^{\circ} \mathrm{C}$, the cellulose content decreases by additional $5 \%$ when residual xylose reaches $23 \%$ of xylose in the native wood. This is in agreement with earlier results reported by Borrega and Sixta (2015), who 
Table 5 Intrinsic viscosity in CED, degree of polymerization and chain scissions number for cellulose from PAA delignified residual solid and original wood

\begin{tabular}{|c|c|c|c|c|}
\hline $\begin{array}{l}\text { Temp } \\
{ }^{\circ} \mathrm{C}\end{array}$ & $\begin{array}{l}\text { Time } \\
\text { min }\end{array}$ & $\begin{array}{l}\text { Visc } \\
\mathrm{cm}^{3} / \mathrm{g}\end{array}$ & $\begin{array}{l}\text { DP } \\
-\end{array}$ & $\begin{array}{l}\text { CSN } \\
-\end{array}$ \\
\hline Original wood & & 810.4 & 607.8 & 0.0 \\
\hline \multirow[t]{3}{*}{130} & 30 & 675.4 & 506.6 & 0.2 \\
\hline & 60 & 741.4 & 556.1 & 0.1 \\
\hline & 120 & 754.2 & 565.7 & 0.1 \\
\hline \multirow[t]{3}{*}{150} & 30 & 794.1 & 595.6 & 0.0 \\
\hline & 60 & 772.7 & 579.5 & 0.0 \\
\hline & 120 & 667.8 & 500.9 & 0.2 \\
\hline \multirow[t]{3}{*}{170} & 30 & 666.9 & 500.2 & 0.2 \\
\hline & 60 & 575.1 & 431.3 & 0.4 \\
\hline & 120 & 519.2 & 389.4 & 0.6 \\
\hline
\end{tabular}

suggested that xylan has a protective function for cellulose and that cellulose content starts to decrease only when residual xylan falls below $25 \%$ of its initial amount.

All of the extraction liquors contain small fractions of glucose. In the beginning of the extraction, glucose can be extracted as a part of the glucomannan and starch. Later, when the autohydrolysis progresses and $\mathrm{pH}$ becomes low enough, glucose may originate from cellulose hydrolysis.

The degradation of cellulose was also investigated by intrinsic viscosity in CED, the results are presented in Table 5. The calculated average chain scission number indicates that there is no cellulose degradation at temperature below $170{ }^{\circ} \mathrm{C}$. The small increase in CSN for the most severe treatments is in agreement with the wood composition results.

For red maple cellulose, scissions up to 3.5 per chain were found; however, this might be due to exposure to low $\mathrm{pH}$ during the entire treatment due to the use of acidic buffer during extraction (Jara et al. 2019).

In an earlier project, in which the same treatment was applied to spruce, cellulose was affected much earlier and 1.2 CSN was achieved after most severe extraction (Wojtasz-Mucha et al. 2020). One of the differences between softwood and hardwood is that in softwood, glucomannan is close to the cellulose fibrils and as most of the glucomannan is extracted early, thus cellulose is left uncovered and more prone to be attacked by protons. In hardwood, the fraction located closest to cellulose fibrils is xylan, that, as discussed above, is more difficult to solubilize and thus to some extent protects the fibrils.

\section{GC-MS}

The presence of uronic acids was confirmed by GC-MS analysis of silylated monomers obtained after methanolysis of the extracted material. Sugar monomers were identified based on samples of known sugars used as standards (Table 6). The results confirmed that the main components of the extracted liquors originated from 
Table 6 Carbohydrate compounds identified in the GC-MS analysis of the freeze-dried liquors extracted at $150{ }^{\circ} \mathrm{C}$

\begin{tabular}{llccccc}
\hline & $\begin{array}{l}10 \mathrm{~min} \\
\%\end{array}$ & $20 \mathrm{~min}$ & $30 \mathrm{~min}$ & $40 \mathrm{~min}$ & $50 \mathrm{~min}$ & $60 \mathrm{~min}$ \\
\hline Galactose & 1.8 & 0.0 & 0.0 & 0.0 & 0.0 & 0.0 \\
Glucose & 28.0 & 8.3 & 2.8 & 0.0 & 3.2 & 4.1 \\
Mannose & 27.2 & 5.7 & 3.1 & 3.1 & 3.3 & 4.3 \\
Xylose & 19.2 & 61.1 & 84.8 & 89.3 & 86.1 & 27.4 \\
Arabinose & 14.7 & 13.6 & 5.0 & 3.9 & 4.4 & 57.9 \\
Glucuronic acid & 1.7 & 4.1 & 1.6 & 2.3 & 3.0 & 3.7 \\
Galacturonic acid & 9.5 & 9.3 & 2.8 & 1.5 & 0.0 & 2.6 \\
\hline
\end{tabular}

The data are presented as relative percentages, with the sugar compounds identified summed up to a total of $100 \%$

glucuronoxylan, as the highest peak in all the samples corresponded to xylose (with the highest fraction detected in liquor collected at 30-40 min).

This result corresponds to the data obtained from ion chromatography presented above (section Glucuronoxylan). Glucuronic acid also originating from GX was detected in all of the samples; however, its concentration was 13-40 times lower than that of xylan. This means that much less glucuronic acid is detected than could be expected based on the birch xylan structure. However, if recalculated against the xylose content detected in liquors after acid hydrolysis, glucuronic acid shows much higher concentration than acetic acid in corresponding samples. Thus, it does contribute to the $\mathrm{pH}$ of the solution. Mannose was detected only in the first sample (0-10 min), while glucose was present in nearly all of the analyzed samples, probably originating mostly from starch and possibly later on in the extraction process from cellulose.

Galactose was present in significant amount early in the extraction and in small quantities later on probably due to extraction of significant fraction of AG early in the extraction process. Arabinose fraction was also significant and increased with prolonged extraction which is not in line with earlier results or the expectations. This result may be due to the methodology used in the evaluation and more precisely due to overlapping signals. It could also originate from pectins, as they can constitute a few percent of wood tissue. An indication of the presence of pectins is also seen in the high fraction of galacturonic acid.

\section{Molecular weight}

The molecular weight of the extracted material was evaluated with GPC equipped with RI and UV detectors: RI detector gives a more general response and includes carbohydrate as well as lignin, and the UV detection is generally responsive to aromatic structures, which implies that it is mainly lignin that is detected. The results are presented in Fig. 5. 

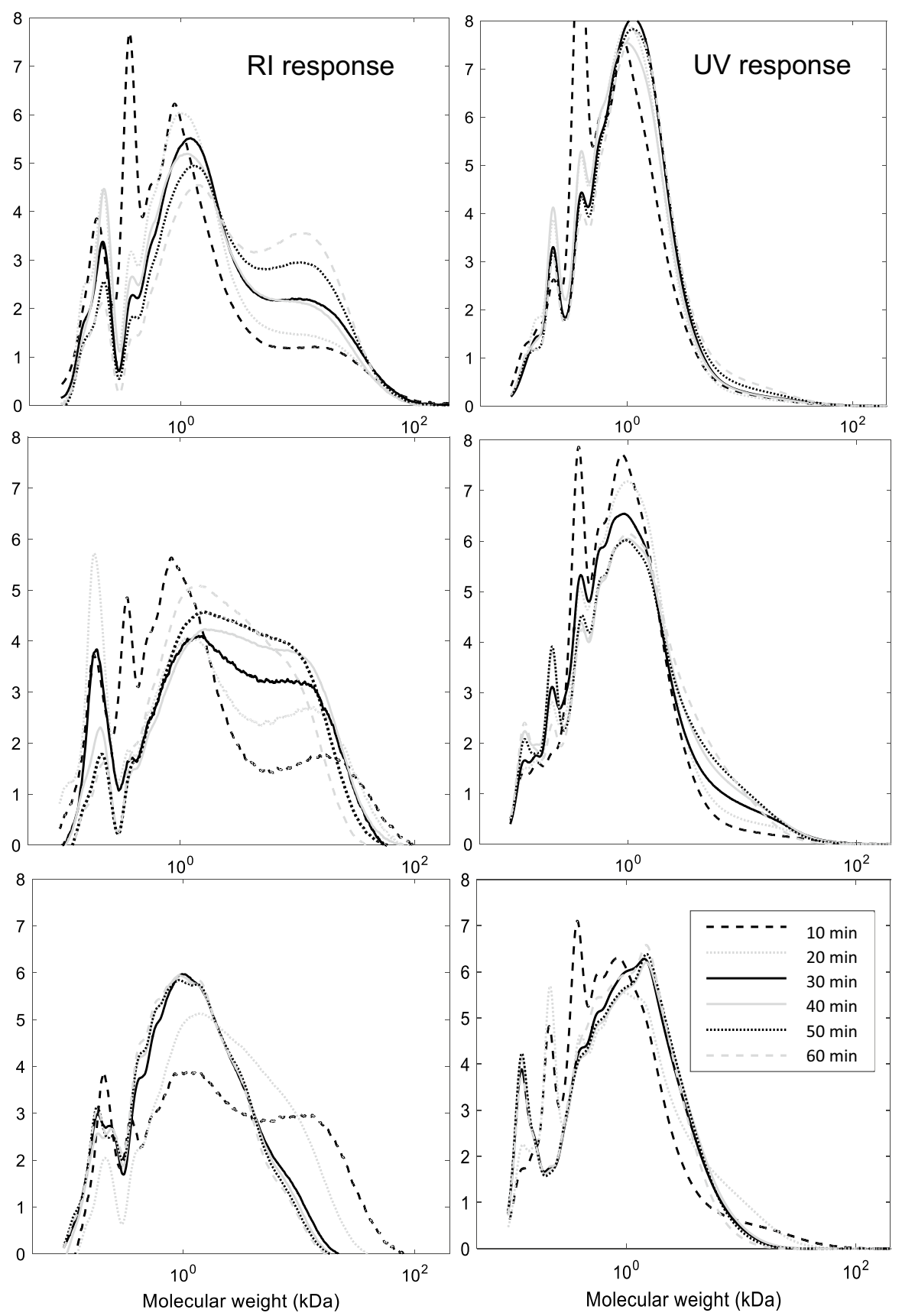

Fig. 5 GPC chromatograms of the extraction liquors obtained at 130 (top), 150 (mid) and $170{ }^{\circ} \mathrm{C}$ (bottom) 
In general, the UV and RI spectra overlap partially at all conditions which indicates the possibility of LCCs. Moreover, the comparison of the chromatograms obtained for liquors extracted at different conditions shows, yet again, that the temperature had a big impact on the molecular mass of the extracted material.

The RI spectra for liquors obtained at all of the studied temperatures show a kink in the region corresponding to structures above $10 \mathrm{kDa}$. The modest UV response in this region suggests that the discussed fraction mainly contains carbohydrates: in the RI spectra at $130{ }^{\circ} \mathrm{C}$, the response becomes stronger in time; at $150{ }^{\circ} \mathrm{C}$, it is negligible for the first sample, biggest for the samples collected at 20 and $30 \mathrm{~min}$ and moves toward lower $\mathrm{Mw}$ after longer extraction time; treatment at the highest temperature results in a signal appearing in this region only for the two earliest collected samples.

This behavior correlates to the amounts of arabinose and galactose detected in the extracted liquors (see Table 3), thus it may be concluded that a high-molecular arabinogalactan is present in the samples. Native arabinogalactan has an average molecular mass of $22 \mathrm{kDa}$ (Willför et al. 2002), so it might be undergoing some hydrolysis prior to extraction. Another possibility is the release of high molecular pectins from middle lamella and primary cell wall exposed by grinding.

Among the high molecular fraction, a peak corresponding to $\mathrm{Mw}$ of $5.4 \mathrm{kDa}$ is visible in the RI chromatograms for liquors extracted at 170 and at $150{ }^{\circ} \mathrm{C}$ for residence times longer than $20 \mathrm{~min}$. Considering the low UV response in this region and the previous finding by Kilpeläinen et al. (2014) showing xylan with molecular mass of $2-8 \mathrm{kDa}$, it can be assumed that this may be a fraction of high molecular weight xylan free from lignin or at least with very small amounts of lignin. Since this fraction cannot be found at $130{ }^{\circ} \mathrm{C}$, it can be assumed that a certain grade of hydrolysis of the wood matrix needs to be achieved before xylan can be dissolved/eluted. There are two mechanisms that can promote extraction-depolymerization into shorter fragments and hydrolysis of the LC bonds. It seems as if both are of importance as $\mathrm{Mw}$ is lower than that of native wood and the UV signal in this region seems to decrease in time possibly indicating the release of a more or less lignin-free xylan.

A relatively broad peak centered around $1.5 \mathrm{kDa}$ is visible in all of the recorded chromatograms in both RI and UV. Moreover, a xylan fraction of molecular weight of ca. $1 \mathrm{kDa}$ was identified earlier in other hot water extraction attempts (Chen et al. 2010; Borrega et al. 2011; Kilpel"ainen et al. 2014). The signal at elution time corresponding to 380 Da may also be a fraction of LCC.

The lowest Mw peak in RI (also visible in UV), approximately $210 \mathrm{Da}$, cannot be simply associated with sugar monomers, as a pentose unit has Mw of $150 \mathrm{Da}$. The UV chromatograms also contain an even lower peak that might indicate the presence of some degradation products, as was earlier indicated for spruce pretreated in the same way (Wojtasz-Mucha et al. 2020).

\section{NMR}

$\mathrm{HSQC}$ spectra obtained for liquors extracted at $150^{\circ} \mathrm{C}$ (Figures S1-S8 in Electronic Supplementary Material) confirm the presence of both lignin and carbohydrates. 
Table 7 Assignment of main lignin and carbohydrate signals in HSQC spectra of samples of liquor extracted at $150{ }^{\circ} \mathrm{C}$ at times $0-40 \mathrm{~min}$

\begin{tabular}{|c|c|c|c|c|c|c|c|c|c|}
\hline$\delta_{\mathrm{C}} / \delta_{\mathrm{H}}$ & Assignment & 10 & 20 & 30 & 40 & 60 & 80 & 100 & 120 \\
\hline \multicolumn{10}{|l|}{ Lignin } \\
\hline \multicolumn{10}{|c|}{ Side chain region $50-90 / 2.5-6.0$} \\
\hline $55.6 / 3.73$ & methoxyl & 1 & 1 & 1 & 1 & 1 & 1 & 1 & 1 \\
\hline $71.8 / 4.86$ & $\beta-\mathrm{O}-4^{\prime}$ aryl ether & 1 & 1 & 1 & 1 & 1 & 1 & 1 & \\
\hline $85.9 / 4.12$ & $\begin{array}{l}\beta-\mathrm{O}-4^{\prime} \text { aryl ether } \\
\text { S-lignin }\end{array}$ & 1 & 1 & 1 & 0 & 1 & 1 & 1 & \\
\hline $86.8 / 3.99$ & $\beta-\mathrm{O}-4^{\prime}$ aryl ether & 1 & 1 & 1 & 1 & 1 & 1 & 1 & \\
\hline $83.9 / 4.29$ & aryl ether & 1 & $\mathrm{~W}$ & $\mathrm{~W}$ & 0 & $\mathrm{~W}$ & 0 & $\mathrm{~W}$ & \\
\hline $59.5-59.7 / 3.40-3.63$ & aryl ether & 1 & 1 & 1 & 1 & 1 & 1 & 1 & \\
\hline $84.8 / 4.65$ & resinol & 1 & 1 & 1 & 1 & 1 & 1 & 1 & \\
\hline $71.0 / 4.18$ & $\beta-\beta^{\prime}$ in p-coumary & 1 & 1 & 1 & 1 & 1 & 1 & 1 & \\
\hline $53.5 / 4.06$ & $\beta-\beta^{\prime}$ in resinol & 1 & 1 & 1 & 1 & 1 & 1 & 1 & \\
\hline \multicolumn{10}{|c|}{ Aromatic region $100-135 / 5.5-8-5$} \\
\hline $103.8 / 6.71$ & S-lignin & 1 & 1 & 1 & 1 & S & $\mathrm{S}$ & S & \\
\hline $110.9 / 6.98$ & G-lignin & $\mathrm{S}$ & 1 & 0 & 0 & 0 & 0 & 0 & \\
\hline $114.9 / 6.77$ & G-lignin & $\mathrm{S}$ & 1 & 1 & $\mathrm{~W}$ & 1 & 1 & 1 & \\
\hline $119.0 / 6.8$ & G-lignin & $\mathrm{S}$ & 1 & 1 & $\mathrm{~W}$ & 1 & 1 & 1 & \\
\hline $128.4 / 6.44$ & p-hydroxycinnamyl & 1 & 1 & 1 & 1 & 1 & 1 & 1 & \\
\hline $153.5 / 7.60$ & cinnamaldehyde & 1 & 1 & 1 & 1 & 1 & 1 & 1 & \\
\hline $126.1 / 6.76$ & cinnamaldehyde & 1 & 1 & 1 & 1 & 1 & 1 & 1 & \\
\hline $113.3 / 6.22$ & Spirodienone & 1 & 0 & 0 & 0 & 0 & 0 & 0 & \\
\hline \multicolumn{10}{|l|}{ Carbohydrates } \\
\hline \multicolumn{10}{|c|}{ Anomeric region 90-105/2.5-6.0 } \\
\hline $73.2 / 4.49$ & 3-O-acetyl- $\beta-\mathrm{d}-\mathrm{Xyl}$ & $\mathrm{W}$ & 1 & 1 & 1 & 1 & 1 & 1 & \\
\hline $74.7 / 4.80$ & 2-O-acetyl- $\beta$-d-xyl & $\mathrm{W}$ & 1 & 1 & 1 & S & $\mathrm{S}$ & $\mathrm{S}$ & \\
\hline $72.5 / 3.02$ & Xyl & 1 & 1 & 1 & 1 & $\mathrm{~S}$ & $\mathrm{~S}$ & $\mathrm{~S}$ & \\
\hline $73.7 / 3.22$ & Xyl & 1 & 1 & 1 & 1 & $\mathrm{~S}$ & $\mathrm{~S}$ & $\mathrm{~S}$ & \\
\hline $75.4 / 3.60$ & Xyl & $\mathrm{W}$ & 1 & 1 & 1 & $\mathrm{~S}$ & $\mathrm{~S}$ & $\mathrm{~S}$ & \\
\hline $81.1 / 3.1$ & 4-O-methyl- $\alpha$-d-GlcUA & 0 & 0 & 0 & 1 & 1 & 1 & 1 & \\
\hline \multicolumn{10}{|c|}{ Aliphatic region 50-90/3.9-5.4 } \\
\hline $99.4 / 4.52$ & $\mathrm{X} 2$-acetyl & 0 & 1 & 1 & 1 & 1 & 1 & 1 & \\
\hline $101.6 / 4.32$ & X3-acetyl & 0 & 1 & 1 & 1 & 1 & 1 & 1 & \\
\hline $98.9 / 4.71$ & X23-acetyl & W & $\mathrm{W}$ & 1 & 1 & 1 & 1 & 1 & \\
\hline $103.2 / 4.20$ & non acetylated & 1 & 1 & 1 & 1 & 1 & 1 & 1 & \\
\hline $92.2 / 4.88$ & $\mathrm{X}$ reducing end & 1 & 1 & 1 & 1 & $\mathrm{~S}$ & $\mathrm{~S}$ & $\mathrm{~S}$ & \\
\hline $97.4 / 4.28$ & $\mathrm{X}$ reducing end & 1 & 1 & 1 & 1 & $\mathrm{~S}$ & $\mathrm{~S}$ & S & \\
\hline $97.2 / 5.18$ & 4- $O$-methyl- $\alpha$-d-GlcUA & 0 & 0 & 0 & $\mathrm{~W}$ & 1 & 1 & 1 & \\
\hline \multicolumn{10}{|l|}{$L C C$} \\
\hline $98.4 / 4.9$ & PhGlc & 0 & 0 & 0 & 0 & 1 & 1 & 0 & \\
\hline $100.6 / 4.65$ & PhGlc & 0 & 0 & 0 & W & 1 & 1 & 1 & \\
\hline $100.5 / 4.79$ & PhGlc & 0 & 0 & 0 & W & 1 & 1 & 1 & \\
\hline
\end{tabular}

Values 1 and 0 correspond to the presence or absence of signal in question (based on Yuan et al. 2011) $w$ weak, $s$ strong 
They differed in terms of detected xylan and lignin structures as discussed below. The assigned NMR crosssignals are presented in Table 7.

Xylan was the only hemicellulose that was clearly identified in the analyzed samples. This was expected since it is the only carbohydrate that potentially could have sufficiently high concentration to be detected. Signals corresponding to C3 or C4 acetylated xylose were not present in the initial sample but appeared in the samples from liquors collected later in the extraction. It is in agreement with the data obtained for acetic acid at $150{ }^{\circ} \mathrm{C}$ (Fig. 2d), as the material extracted in the beginning of the treatment contained low quantity of acetate.

The spectra of extracts obtained after more than 40 min of treatment show increased intensity of signals assigned to xylose reducing ends, suggesting higher fraction of low-molecular xylan (therefore more chain ends).

Signals originating from glucuronic acid were only detected for samples collected later than 30 min of extraction.

The difference between analyzed spectra in the context of lignin structure is related to the strong guaiacyl signal in the first sample in comparison with the following liquors. Moreover, it seems that the syringyl peaks gain intensity in the liquors collected later than 60 min of extraction.

Slightly different lignin structures present at different extraction times could be related to the proposed model with different types of lignin present in the secondary cell wall. Ruel et al. (2006) suggested that condensed guaiacyl lignin, bound with hemicelluloses is assembled closely to the cellulose microfibrils, while the interfibrillar spaces are filled with a matrix built of non-condensed guaiacyl-syringyl lignin. However, it is possible that we only see the less condensed structures, as the lignin removal is not complete at the conditions used in this paper.

Due to high concentration of xylan and lignin in the sample, the phenyl glycoside linkages LC-bonds could be detected in the NMR spectra. These are visible in samples after 30 min of extraction.

The indications of the presence of high molecular lignin-free xylan and gradual increase in content of short LCC with short xylan chains do not necessarily imply the presence of two different lignin structures in wood. It is possible that the random depolymerization of the cell wall matrix leads to release of smaller structures of limited solubility. Pure xylan fragment would probably require less depolymerization for dissolution than LCC fragments as the 3D aromatic lignin structure will make the solubilization more difficult.

\section{Summary}

While investigating the mechanism of autohydrolysis, three main questions were considered: What is the driving force behind the acidification of reaction media, how does it correlate to the topochemistry of the cell wall matrix and how does its decomposition in the course of autohydrolysis proceed.

To start with, the initial conditions need to be considered: The untreated moist birch tissue is acidic due to the presence of free acids and acidic groups that can be easily released from different wood constituents (Fengel and Wegener 1984). 
However, despite the relatively high concentration of protons in the cell wall, autohydrolysis reactions are not significant at low temperatures. The rates of these reactions increase only when the temperature is raised. Only then the acidic hydrolysis of different chemical bonds in the wood matrix leads to partial depolymerization, deacetylation and degradation of hemicelluloses and lignin.

Generation of free acetic acid could be a rate-determining step in the beginning of the extraction and at lower treatment temperatures. At that point, the $\mathrm{pH}$ in the tissue is a result of a weak-acid equilibrium of acetic acid (Kapu et al. 2016). When sufficient amount of acetic acid is generated, the $\mathrm{pH}$ decreases leading to an increase in the reaction rate for different hydrolytic reactions. That in turn results in release of other organic acids leading to faster depolymerization and dissolution of the wood constituents. However, due to the extraction of wood constituents, the concentration of structures (e.g., released acetyl and glucuronic acid groups) that can contribute to acidity decreases and, thus, the autohydrolysis process slows down.

Based on the present results made in the flow-through reactor, the deacetylation seems to be occurring mostly in the cell wall. This is supported by the availability of the substrates as the deacetylation is driven by the concentration of the protons and acetylated xylan. The concentrations are initially high in the cell wall and decrease in time, however they probably remain high in comparison with the concentration in the extraction liquor as in this setup constant flow of freshwater is provided. Moreover, quick cooling of the liquors quenches the possible reactions. The deacetylation in reaction media might however become significant in a batch reactor, where xylan and acetic acid would accumulate in the bulk solution.

An initial temperature-driven acidification originating from deacetylation but possibly also a release of GlcA-whether free or xylan-bound-will promote further hydrolytic reactions on xylan including depolymerization and continued deacetylation, both in turn facilitating even further self-catalyzed acidification and degradation (through release of xylan fragments and its side groups).

A dependence between temperature and $\mathrm{pH}$, extraction yield and depolymerization of lignin and hemicelluloses was observed. A possible explanation is that as the deacetylation and various hydrolysis reactions progress, hemicelluloses of various molecular weight can be found in the liquors together with lignin, sugar monomers and possibly degradation products. The deacetylation is governed by the temperature, and this relation translates into rate of the hydrolytic reactions as they depend on proton generation.

As mentioned before, two types of xylan are widely discussed in the literature, one type with more acetylated and less branched xylan interacting closely with cellulose and another with more branched xylan bound to lignin (Ruel et al. 2006; Dammström et al. 2009). Here, both a high molecular lignin-free xylan fraction was detected, and a xylan fraction with lignin bound to it. Both fractions could originate from the same LLC structures between the cellulose fibrils: During the hydrolysis, some of the xylan may have been completely decoupled from the lignin, while other part of the xylan remained bound with lignin forming LCC structures. Moreover, each treatment resulted in a certain fraction of xylan retained in the wood, corresponding to cellulose-associated xylan. 
The present NMR results indicate that lignin which is extracted at short residue times mainly consists of guaiacyl units. Dammström et al. (2009) suggested that this type of lignin is more condensed and closely associated with the cellulose fibrils. As the autohydrolysis progresses, more syringyl structures and LCC become visible in the NMR spectra. This type of lignin has been suggested to be located in between the cellulose fibrils (Dammström et al. 2009), and it is probably the high Mw and the big size of the highly complicated LCC structures that need to be degraded before extraction.

It can be concluded that the removal of xylose and lignin becomes more efficient as the autohydrolysis progresses. It seems that there is a random cleavage of glycosidic, LC and lignin bonds resulting in elution of high molecular mass xylan and increasing fraction of shorter xylose chains bound to lignin. Furthermore, as the hydrolysis progresses, more constituents become more easily available but it will also be easier for the solubilized constituents to be transported out of the cell wall.

\section{Conclusion}

Flow-through extraction allowed in this study high extraction yields and a good insight into the hot-water extraction process.

The generation of protons via release of organic acids in the cell wall is of utmost importance for the deacetylation and dissolution of hemicelluloses in wood. Interestingly though, most of the acetates remain bound to the hemicelluloses and the release of free acetic acid has a limited contribution to $\mathrm{pH}$ decrease.

Indication of three xylan fractions was found: a high-molecular lignin-free fraction, a relatively short-chain xylan bound in the LCC (both of these fractions were probably dissolved into the extraction liquor) and a hard-to-extract fraction that remained in the solid residue.

Furthermore, indications of xylan-free and xylan-bound lignin fractions were detected differing in guaiacyl and syringyl content.

Cellulose was affected by the process to a minor extent with 0.6 chain scissions introduced upon extraction at the most severe conditions. Arabinogalactan was extracted both in high Mw form and as free monomers.

Supplementary Information The online version contains supplementary material available at https://doi. org/10.1007/s00226-021-01283-9.

Acknowledgements The Knut and Allice Wallenberg Foundation is gratefully acknowledged for financial support within Wallenberg Wood Science Center and The Swedish NMR Center is acknowledged for spectrometer time.

Funding Open access funding provided by Chalmers University of Technology. 


\section{Compliance with ethical standard}

Conflict of interest The authors declare that they have no conflict of interest.

Open Access This article is licensed under a Creative Commons Attribution 4.0 International License, which permits use, sharing, adaptation, distribution and reproduction in any medium or format, as long as you give appropriate credit to the original author(s) and the source, provide a link to the Creative Commons licence, and indicate if changes were made. The images or other third party material in this article are included in the article's Creative Commons licence, unless indicated otherwise in a credit line to the material. If material is not included in the article's Creative Commons licence and your intended use is not permitted by statutory regulation or exceeds the permitted use, you will need to obtain permission directly from the copyright holder. To view a copy of this licence, visit http://creativecommons.org/licen ses/by/4.0/.

\section{References}

Ahmad W, Kuitunen S, Pranovich A, Alopaeus V (2018) Physicochemical modeling for pressurized hot water extraction of spruce wood. Ind Eng Chem Res. https://doi.org/10.1021/acs.iecr.8b050 97

Bogren J, Brelid H, Karlsson S, Theliander H (2009) Can the delignification rate be affected by previously applied cooking conditions? Nord Pulp Pap Res J 24(17):25-32

Borrega M, Sixta H (2015) Water prehydrolysis of birch wood chips and meal in batch and flow-through systems: a comparative evaluation. Ind Eng Chem Res. https://doi.org/10.1021/acs.iecr.5b00908

Borrega M, Nieminen K, Sixta H (2011) Degradation kinetics of the main carbohydrates in birch wood during hot water extraction in a batch reactor at elevated temperatures. Bioresour Technol 102(22):10724-10732. https://doi.org/10.1016/j.biortech.2011.09.027

Bouchard J, Nguyen TS, Chornet E, Overend RP (1991) Analytical methodology for biomass pretreatment. Part 2: Characterization of the filtrates and cumulative product distribution as a function of treatment severity. Bioresour Technol 36(2):121-131. https://doi.org/10.1016/0960-8524(91)90169-K

Chen X, Lawoko M, Av H (2010) Kinetics and mechanism of autohydrolysis of hard-woods. Biores Technol 101(20):7812-7819. https://doi.org/10.1016/j.biortech.2010.05.006

Chen GG, Qi XM, Guan Y, Peng F, Yao CL, Sun RC (2016) High strength hemicellulose-based nanocomposite film for food packaging applications. ACS Sustain Chem Eng. https://doi.org/10.1021/ acssuschemeng.5b01252

Conner AH (2007) Kinetic modeling of hardwood prehydrolysis. Part I. Xylan removal by water prehydrolysis. Wood Fiber Sci 16(2):268-277. URL https://wfs.swst.org/index.php/wfs/article/view/1823

Dammström S, Salmen L, Gatenholm P (2009) On the interactions between cellulose and xylan, a biomimetic simulation of the hardwood cell wall. BioResources 4(1):3-14

Escalante A, Gonçalves A, Bodin A, Stepan A, Sandström C, Toriz G, Gatenholm P (2012) Flexible oxygen barrier films from spruce xylan. Carbohyd Polym 87(4):2381-2387. https://doi.org/10.1016/j. carbpol.2011.11.003

Fengel D, Wegener G (1984) Wood-chemistry, ultrastructure, reactions. Walter de Gruyter, Berlin and New York,. https://doi.org/10.1007/BF02608943

Gallina G, Cabeza Á, Biasi P, García-Serna J (2016) Optimal conditions forhemicelluloses extraction from Eucalyptus globulus wood: hydrothermal treatment in a semi-continuous reactor. Fuel Process Technol 148:350

Gao C, Ren J, Zhao C, Kong W, Dai Q, Chen Q, Liu C, Sun R (2016) Xylan-based temperature/pH sensitive hydrogels for drug-controlled release. Carbohydr Polym 151:189-197. https://doi.org/10.1016/j. carbpol.2016.05.075

Garrote G, Domínguez H, Parajó JC (1999) Mild autohydrolysis: an environmentally friendly technology for xylooligosaccharide production from wood. J Chem Technol Biotechnol 74(11):1101-1109. https://doi.org/10.1002/(SICI)1097-4660(199911)74:11\%3c1101::AID-JCTB146\%3e3.0.CO;2-M

Garrote G, Domínguez H, Parajó JC (2001) Study on the deacetylation of hemicelluloses during the hydrothermal processing of Eucalyptus wood. Holz Roh Werkst 59(1):53-59. https://doi.org/10. 1007/s001070050473 
Grénman H, Eränen K, Krogell J, Willför S, Salmi T, Murzin DY (2011) Kinetics of aqueous extraction of hemicelluloses from spruce in an intensified reactor system. Indus Eng Chem Res 50(7):38183828. https://doi.org/10.1021/ie101946c

Holgate HR, Meyer JC, Tester JW (1995) Glucose hydrolysis and oxidation in supercriticalwater. AIChE J 41(3):637-648. doi: https://doi.org/10.1002/aic.690410320. URL: https://aiche.onlinelibrary. wiley.com

Immergut EH, Schurz J, Mark H (1953) Viskositätszahl-Molekulargewichts-Beziehung für Cellulose und Untersuchungen von Nitrocellulose in verschiedenen Lösungsmitteln. Monatshefte für Chemie 84(2):219-249. doi: https://doi.org/10.1007/BF00899186

Jara R, Lawoko M, van Heiningen A (2019) Intrinsic dissolution kinetics and topochemistry of xylan, mannan, and lignin during auto-hydrolysis of red maple wood meal. Can J Chem Eng 97(3):649661. https://doi.org/10.1002/cjce.23373

Kale G, Kijchavengkul T, Auras R, Rubino M, Selke SE, Singh SP (2007) Compostability of bioplastic packaging materials: an overview. Macromol Biosci 7(3):255-277. https://doi.org/10.1002/mabi. 200600168

Kapu NS, Yuan Z, Chang XF, Beatson R, Martinez DM, Trajano HL (2016) Insight into the evolution of the proton concentration during autohydrolysis and dilute-acid hydrolysis of hemicellulose. Biotechnol Biofuels 9(1):1-10. https://doi.org/10.1186/s13068-016-0619-6

Kilpeläinen P, Leppäanen K, Spetz P, Kitunen V, Pranovich A, Ilvesniemi H, Willför S (2012) Pressurised hot water extraction of acetylated xylan from birch sawdust. Nord Pulp Pap Res J 27:680. https://doi.org/10.3183/NPPRJ-2012-27-04-p680-688

Kilpeläinen P, Kitunen V, Hemming J, Pranovich A, Ilvesniemi H, Willför S (2014) Pressurized hot water flow-through extraction of birch sawdust-effects of sawdust density and sawdust size. Nord Pulp Pap Res J 29:547. https://doi.org/10.3183/npprj-2014-29-04-p547-556

Kohn R, Kovac P (1978) Dissociation constants of d-galacturonicand d-glucuronic acid and their o-methyl derivatives. Chem zvesti 32:478

Kuitunen S, Vuorinen T, Alopaeus V (2013) The role of Donnan effect in kraft cooking liquorimpregnation and hot water extraction of wood. Holzforschung 67. doi: 10.1515/hf-2012-0187

Kumar R, Hu F, Hubbell CA, Ragauskas AJ, Wyman CE (2013) Comparison of laboratory delignification methods, their selectivity, and impacts on physiochemical characteristics of cellulosic biomass. Biores Technol 130:372-381. https://doi.org/10.1016/j.biortech.2012.12.028

Lachowicz H, Wróblewska H, Sajdak M, Komorowicz M, Wojtan R (2019) The chemical composition of silver birch (Betula pendula Roth.) wood in Poland depending on forest stand location and forest habitat type. Cellulose 26(5):3047-3067. https://doi.org/10.1007/s10570-019-02306-2

Laser M, Schulman D, Allen SG, Lichwa J, Antal MJ Jr, Lynd LR (2002) A comparison of liquid hot water and steam pretreatments of sugar cane bagasse for bioconversion to ethanol. Biores Technol 81(1):33-44. https://doi.org/10.1016/S0960-8524(01)00103-1

Lehtonen M, Merinen M, Kilpeläinen PO, Xu C, Willför SM, Mikkonen KS (2018) Phenolic residues in spruce galactoglucomannans improve stabilization of oil-in-water emulsions. J Colloid Interface Sci 512:536-547. https://doi.org/10.1016/j.jcis.2017.10.097

Leppänen K, Spetz P, Pranovich A, Hartonen K, Kitunen V, Ilvesniemi H (2011) Pressurized hot water extraction of Norway spruce hemi000000celluloses using a flow-through system. Wood Sci Technol 45(2):223-236. https://doi.org/10.1007/s00226-010-0320-z

Lindblad MS, Albertsson AC, Ranucci E, Laus M, Giani E (2005) Biodegradable polymers from renewable sources: rheological characterization of hemicellulose-based hydrogels. Biomacromol 6(2):684690. https://doi.org/10.1021/bm049515z

Lora JH, Wayman M (1978) Delignification of hardwoods by autohydrolysis and extraction. TAPPI 61(6):47-50

Markstedt K, Xu W, Liu J, Xu C, Gatenholm P (2017) Synthesis of tunable hydrogels based on O-acetylgalactoglucomannans from spruce. Carbohyd Polym 157:1349-1357. https://doi.org/10.1016/j. carbpol.2016.11.009

Mikkonen KS, Heikkilä MI, Helén H, Hyvönen L, Tenkanen M (2010) Spruce galactogluco-mannan films show promising barrier properties. Carbohydr Polym 79(4):1107-1112. https://doi.org/10. 1016/j.carbpol.2009.10.049

Mikkonen KS, Tenkanen M (2012) Sustainable food-packaging materials based on future biorefinery products: xylans and mannans. Trends Food Sci Technol 28(2):90-102. https://doi.org/10.1016/j. tifs.2012.06.012 
Overend RP, Chornet E, Gascoigne JA (1987) Fractionation of lignocellulosics by steam-aqueous pretreatments [and discussion]. Philos Trans R Soc A Math Phys Eng Sci. https://doi.org/10.1098/rsta. 1987.0029

Prakasham RS, Sreenivas Rao R, Hobbs PJ (2009) Current trends in biotechnological production of xylitol and future prospects. Curr Trends Biotechnol Pharm 3: 8-36. Accessed 12 Feb 2020

Ruel K, Chevalier-Billosta V, Guillemin F, Berrio-Sierra J, Joseleau JP (2006) The wood cell wall at the ultrastructural scale-formation and topochemical organization. Maderas Ciencia y Tecnología 8(2). doi: https://doi.org/10.4067/S0718-221X2006000200004

Sixta H (2006) Handbook of Pulp. Wiley. https://doi.org/10.1002/9783527619887

Song T, Pranovich A, Sumerskiy I, Holmbom B (2008) Extraction of galactoglucomannan from spruce wood with pressurised hot water. Holzforschung 62(6):659-666. https://doi.org/10.1515/HF.2008. 131

Song T, Pranovich A, Holmbom B (2012) Hot-water extraction of ground spruce wood of different particle size. BioResources 7(3):4214-4225

Stevanic JS, Bergström EM, Gatenholm P, Berglund L, Salmén L (2012) Arabinoxy-lan/nanofibrillated cellulose composite films. J Mater Sci 47(18):6724-6732. https://doi.org/10.1007/ s10853-012-6615-8

Sundherg A, Sundherg K, Lillandt C, Holmhom B (1996) Determination of hemicelluloses and pectins in wood and pulp fibres by acid methanolysis and gas chromatography. Nord Pulp Pap Res J 11(4):216-219. https://doi.org/10.3183/npprj-1996-11-04-p216-219

Sundqvist B, Karlsson O, Westermark U (2006) Determination of formic-acid and acetic acid concentrations formed during hydrothermal treatment of birch wood and its relation to colour, strength and hardness. Wood Sci Technol 40(7):549-561. https://doi.org/10.1007/s00226-006-0071-z

Tarasov D, Leitch M, Fatehi P (2018) Flow through autohydrolysis of spruce wood chips and lignin carbohydrate complex formation. Cellulose 25(2):1377-1393. https://doi.org/10.1007/s10570-017-1643-9

Teleman A, Harjunpää V, Tenkanen M, Buchert J, Hausalo T, Drakenberg T, Vuorinen T (1995) Characterisation of 4-deoxy-beta-1-threo-hex-4-enopyranosyluronic acid attached to xylan in pine kraft pulp and pulping liquor by $1 \mathrm{~h}$ and $13 \mathrm{c} \mathrm{nmr}$ spectroscopy. Carbohydr Res 272(1):55-71. https://doi. org/10.1016/0008-6215(95)96873-m

Timell TE (1969) The chemical composition of tension wood. Svensk Papperstidning 7:173-181

Tunc MS, van Heiningen ARP (2008) Hemicellulose extraction of mixed southern hard- wood with water at $150 \mathrm{C}$ : effect of time. Ind Eng Chem Res 47(18):7031-7037. https://doi.org/10.1021/ie8007105

Valoppi F, Maina N, Allén M, Miglioli R, Kilpeläinen PO, Mikkonen KS (2019) Spruce galactoglucomannan-stabilized emulsions as essential fatty acid delivery systems for functionalized drinkable yogurt and oat-based beverage. Eur Food Res Technol 245(7):1387-1398. https://doi.org/10.1007/ s00217-019-03273-5

Willför S, Sjöholm R, Laine C, Holmbom B (2002) Structural features of water-soluble arabinogalactans from Norway spruce and Scots pine heartwood. Wood Sci Technol 36(2):101-110. https://doi.org/ 10.1007/s00226-001-0137-x

Wojtasz-Mucha J (2020) Pre-extraction of wood components-mild hydrothermal methods for a future materials biorefinery. Doctoral thesis. Chalmers University of Technology, https://research.chalm ers.se/publication/518454

Wojtasz-Mucha J, Hasani M, Theliander H (2017) Hydrothermal pretreatment of wood by mild steam explosion and hot water extraction. Biores Technol 241:120-126. https://doi.org/10.1016/j.biortech. 2017.05.061

Wurm FR, Weiss CK (2014) Nanoparticles from renewable polymers. Front Chem 2. https://doi.org/10. 3389/fchem.2014.00049

Yuan TQ, Sun SN, Xu F, Sun RC (2011) Characterization of lignin structures and lignin-carbohydrate complex (LCC) linkages by quantitative 13C and 2D HSQC NMR spectroscopy. J Agric Food Chem 59(19):10604-10614. https://doi.org/10.1021/jf2031549

Zhang P, Whistler RL (2004) Mechanical properties and water vapor permeability of thin film from corn hull arabinoxylan. J Appl Polym Sci 93(6):2896-2902. https://doi.org/10.1002/app.20910

Publisher's Note Springer Nature remains neutral with regard to jurisdictional claims in published maps and institutional affiliations. 